\title{
PRINSIP-PRINSIP MANAJEMEN KEUANGAN SEKOLAH
}

\author{
Oleh: Nur Rahmah \\ Fakultas Tarbiyah dan IImu Keguruan IAIN Palopo \\ email: nurrahmah_85@yahoo.co.id
}

\begin{abstract}
Abstrak:
Untuk mewujudkan pendidikan yang bekualitas, perlu adanya pengelolaan secara menyeluruh dan professional terhadap sumber daya yang ada dalam lembaga pendidikan. Salah satu sumber daya yang perlu dikelola dengan baik dalam lembaga pendidikan adalah masalah keuangan. Dalam konteks ini keuangan merupakan sumber dana yang sangat diperlukan sekolah sebagai alat untuk melengkapi berbagai sarana dan prasarana pemelajaran di sekolah, meningkatkan kesejahteraan guru, layanan dan pelaksanaan program supervisi. Oleh karena itu, kepala sekolah sebagai pemimpin pendidikan di sekolah harus mengetahui dan mampu mengelola keuangan sekolah dengan baik, bertanggung jawab dan transparan kepada masyarakat dan pemerintah.
\end{abstract}

\section{Kata Kunci: Prinsip, Manajemen, Keuangan Sekolah}

\section{A. PENDAHULUAN}

Peningkatan kualitas pendidikan bukanlah tugas yang ringan karena tidak hanya berkaitan dengan permasalahan teknis, tetapi mencakup berbagai persoalan yang sangat rumit dan kompleks, baik yang berkaitan dengan perencanaan, pendanaan, maupun efisiensi dan efektivitas penyelenggaraan sistem persekolahan, peningkatan kualitas pendidikan juga menuntut manajemen pendidikan yang lebih baik. Hal ini sesuai dengan hasil penelitian Balitbang Dikbud (1999) menunjukkan bahwa manajemen sekolah merupakan salah satu factor yang memengaruhi kualitas pendidikan.

Untuk mewujudkan pendidikan yang bekualitas, perlu adanya pengelolaan secara menyeluruh dan professional terhadap sumber daya yang ada dalam lembaga pendidikan. Salah satu sumber daya yang perlu dikelola dengan baik dalam lembaga pendidikan adalah masalah keuangan. Dalam konteks ini keuangan merupakan sumber dana yang sangat diperlukan sekolah sebagai alat untuk melengkapi berbagai sarana dan prasarana pemelajaran di sekolah, meningkatkan kesejahteraan guru, layanan dan pelaksanaan program supervisi. Oleh karena itu, kepala sekolah sebagai pemimpin pendidikan di sekolah harus mengetahui dan mampu mengelola keuangan sekolah dengan baik, bertanggung jawab dan transparan kepada masyarakat dan pemerintah. 


\section{B. ADMINSTRASI KEUANGAN SEKOLAH}

Sumber keuangan pada suatu sekolah secara gari besar dapat dikelompokkan atas tiga sumber, yaitu:

1. Pemerintah, baik pemerintah pusat, daerah maupun kedua-duanya, yang bersifat umum atau khusus dan diperuntukkan bagi kepentingan pendidikan

2. Orang tua atau peserta didik

3. Masyarakat, baik mengikat maupun tidak mengikat

Sumber keuangan sekolah ada dua macam, dari pemerintah dan nonpemerintah. Keuangan dari pemerintah yaitu dari uang rutin dan uang pembangunan, sedangkan keuangan dari nonpemerintah yaitu dari SPP dan sumbangan dari orang tua dan masyarakat, baik yang melalui komite sekolah, maupun yang langsung pada kepala sekolah.

Administrasi keuangan dan pertanggungjawabannya ditentukan oleh undangundang. Kekuasaan otorisator dan ordonateur tidak boleh berfungsi sebagai bendaharawan. Otorisator berwenang mengeluarkan otorisasi, tapi dengan otorisasi itu tidak ada kekuasaan mengeluarkan uang dari kas bendaharawan. Ordonateur berhak mengeluarkan surat perintah membayar uang tetapi tidak berhak menggunakannya tanpa otorisasi. Bendaharawan mengeluarkan uang tetapi tidak berhak mengeluarkan uang tanpa pengaturan pemerintah yang berwenang dalam hal ini.

Karena masalah keuangan merupakan masalah yang peka, maka perlu dikelola secara cermat, dan hati-hati. Untuk itu diperlukan pembukuan yang rapi serta benar tentang penerimaan dan pengeluaran uang. Pemegang keuangan itu perlu ditatar mengenai pembukuan keuangan sekolah, prosedur penggunaan keuangan dan pertanggungjawaban.

\section{PENGELOLAAN KEUANGAN SEKOLAH}

Pembiayaan atau pendanaan pendidikan adalah tanggung jawab bersama antara pemerintah pusat, pemerintah daerah dan masyarakat. Tanggung jawab pemerintah pusat dan pemerintah daerah untuk menyediakan anggaran pendidikan berdasarkan prinsip keadilan, kecukupan dan keberlanjutan. Dalam rangka memenuhi tanggung jawab pendanaan tersebut, pemerintah pusat, pemerintah daerah, dan masyarakat mengerahkan 
sumber daya yang ada sesuai dengan peraturan perundang-undangan yang dikelola berdasarkan prinsip keadilan, efisiensi, transparansi, dan akuntabilitas publik.

Pembiayaan pendidikan pada dasarnya menitikberatkan pada upaya pendistribusian benefit pendidikan dan beban yang harus ditanggung masyarakat. Biaya secara sederhana berarti jumlah nilai uang yang dibelanjakan atau jasa pelayanan yang diserahkan pada siswa. Pembiayaan pendidikan berhubungan dengan distribusi beban pajak dalam berbagai jenis pajak, kelompok manusia serta metode pengalihan pajak ke sekolah. Hal yang penting dalam pembiayaan pendidikan adalah berupa besar uang yang harus dibelanjakan, dari mana sumber uang yang diperoleh dan kepada siapa uang harus dialokasikan (Thomas: 12).

Pembiayaan pendidikan dalam system pendidikan nasional diatur dalam Peraturan Pemerintah nomor 48 tahun 2008 tentang pendanaan pendidikan. Pembiayaan pendidikan ini meliputi:

1. Biaya satuan pendidikan yang terdiri dari biaya investasi (terdiri atas biaya investasi lahan pendidikan, dan biaya investasi selain lahan pendidikan). Biaya operasi terdiri atas biaya personalia, dan biaya nonpersonalia. Bantuan biaya pendidikan dan beasiswa.

2. Biaya penyelenggaraan dan/atau pengelolaan pendidikan

3. Biaya pribadi peserta didik.

\section{PRINSIP-PRINSIP MANAJEMEN KEUANGAN SEKOLAH SERTA PENGELOLAANNYA}

1. Prinsip-prinsip manajemen keuangan

Manajemen keuangan sekolah perlu memerhatikan sejumlah prinsip. Undangundang No.20 tahun 2003 pasal 48 menyatakan bahwa pengelolaan dana pendidikan berdasarkan pada prinsip keadilan, efisiensi, transparansi dan akuntabilitas publik. Di samping itu prinsip efektivitas juga perlu mendapat penekanan. Berikut ini dibahas masingmasing prinsip tersebut, yaitu transparansi, akuntabilitas, efektivitas, dan efisiensi.

a) Transparansi

Transparansi berarti keterbukaan. Transparansi di bidang manajemen berarti adanya keterbukaan dalam mengelola suatu kegiatan. Di lembaga pendidikan, 
bidang manajemen keuangan yang transparan berarti adanya keterbukaan dalam manajemen keuangan lembaga pendidikan, yang keterbukaan sumber keuangan dan jumlahnya, rincian penggunaan dan pertanggungjawaban harus jelas sehingga bias memudahkan pihak-pihak yang berkepentingan untuk mengetahuinya. Transparansi keuangan sangat diperlukan dalam rangka meningkatkan dukungan orang tua.

b) Akuntabilitas

Akuntabilitas adalah kondisi seseorang yang dinilai oleh orang lain karena kualitas performasinya dalam menyelesaikan tugas untuk mencapai tujuan yang menjadi tanggung jawabnya. Akuntabilitas di dalam manajemen keuangan berarti penggunaan uang sekolah dapat dipertanggungjawabkan sesuai dengan perencanaan yang telah ditetapkan. (Nur Hamiyah, 2015)

c) Efektivitas

Efektif sering kali diartikan sebagai pencapaian tujuan yang telah ditetapkan. (Garnear: 2004) mendefinisikan efektivitas lebih dalam lagi, karena sebenarnya efektivitas tidak berhenti sampai tujuan tercapai tetapi sampai pada kualitas hasil yang dikaitkan dengan pencapaian visi lembaga yang dicirikan oleh outcome kualitatif.

d) Efisiensi

Efisiensi berkaitan dengan kuantitas hasil suatu kegiatan. Menurut Garner (2004), efisiensi dicirikan oleh outcome kuantitatif. Efisiensi adalah perbandingan yang terbaik antara masukan (input) dan keluaran (output) atau antara daya dan hasil.

2. Prinsip pengelolaan keuangan di sekolah

Penggunaan keuangan didasarkan pada prinsip-prinsip sebagai berikut:

a) Hemat tidak mewah, efisien dan sesuai dengan kebutuhan teknis yang telah disyaratkan

b) Terarah dan terkendali sesuai dengan rencana, program atau kegiatan.

c) Keharusan penggunaan kemampuan

Dalam mengelola keuangan ini, kepala sekolah berfungsi sebagai "otorisator" dan "ordonateur". Sebagai otorisator, kepala sekolah diberi wewenang untuk mengambil 
tindakan yang berkaitan dengan penerimaan atau pengeluaran anggaran. Sedangkan fungsi sebagai ordonateur, kepala sekolah sebagai pejabat yang berwenang melakukan pengujian dan memerintahkan pembayaran atas segala tindakan berdasarkan otorisasi yang telah ditetapkan.

\section{E. KESIMPULAN}

Berdasarkan pemaparan di atas, maka kepala sekolah diharuskan mampu menyusun rencana anggaran dan pendapatan sekolah (RAPBS). Untuk itu kepala sekolah mengetahui sumber-sumber dan yang merupakan sumber daya sekolah. Sumber dana tersebut antara lain meliputi anggaran rutin, dana penunjang pendidikan (DPD), subsidi bantuan penyelenggaraan pendidikan (SBPP), bantuan operasional dan perawatan (BOP), bantuan operasional sekolah (BOS), (BP3), donator, badan usaha, serta sumbangan lainlain. Untuk sekolah-sekolah swasta sumber dana berasal dari SPP, subsidi pemerintah, yayasan, dan masyarakat secara luas.

\section{DAFTAR PUSTAKA}

B. Suryosubroto, Drs. 2004. Manajemen Pendidikan di Sekolah. Jakarta: Rineka Cipta. Depdikbud. 1999. Panduan Manajemen Sekolah. Jakarta: Direktorat Dikmenum.

Harniyah, Nur. Pengantar manajemen Pendidikan di Sekolah. 2015. Jakarta: Prestasi Pustaka

Mulyasa, E. 2004. Menjadi Kepala Sekolah Profesional. Bandung: PT. Rosda Karya.

Undang-Undang Sistem Pendidikan Nasional Nomor 20 Tahun 2003 tentang Sistem Pendidikan Nasional. 